\title{
DESKRIPSI HAMBATAN DAN KESULITAN GURU FISIKA SMA SE-KABUPATEN REJANG LEBONG DALAM MENERAPKAN KURIKULUM 2013
}

\author{
Zikri Alfandry ${ }^{*}$, Rosane Medriati, Nyoman Rohadi \\ Program Studi S1Pendidikan Fisika FKIP Universitas Bengkulu \\ Jalan. W.R Supratman Kandang Limun, Bengkulu \\ e-mail*1: zikrialfandry99@gmail.com
}

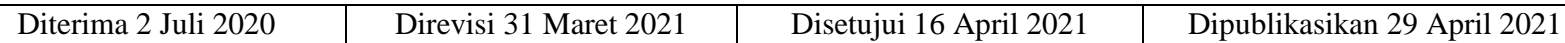
https://doi.org/10.33369/jkf.4.1.1-8

\begin{abstract}
ABSTRAK
Penelitian ini merupakan penelitian deskriptif kualitatif metode survey yang bertujuan untuk mendeskripsikan masalahmasalah yang dialami guru fisika SMA se-kabupaten rejang lebong dalam menerapkan kurikulum 2013. Subjek penelitian ini adalah 9 guru fisika sma yang terdiri dari 3 orang masing-masing sekolah yaitu SMA 1, SMA 2 dan SMA 8 Kabupaten Rejang Lebong. Penelitian ini dilakukan dengan cara pengisian angket dan wawancara responden. Hasil penelitian ini menunjukkan bahwa hambatan yang dialami guru dalam menerapkan kurikulum 2013 pada tahap perencanaan sebesar $48 \%$, tahap pelaksanaan sebesar 51,49\% dan tahap evaluasi sebesar 55,79\%. kesulitan yang dihadapi guru dalam menerapkan kurikulum 2013 pada tahap perencanaan sebesar 75,56\%, tahap pelaksanaan sebesar 92,93\% dan tahap evaluasi sebesar 94,14\%. Berdasarkan hasil penelitian dapat disimpulkan bahwa guru mengalami kesulitan dan hambatan dalam menerapkan kurikulum 2013.
\end{abstract}

Kata kunci: Kurikulum 2013, Kesulitan guru, Hambatan guru, Tahap perencanaan, Tahap pelaksanaan, dan Tahap evaluasi.

\section{ABSTRACT}

This research was a qualitative descriptive research survey method that aimed to describe the problems Rejang Lebong district high school physics teacher in implementing the 2013 curriculum. The subject of this research was the 9 teachers of physics, consisting of 3 individual schools, namely SMA 1, SMA 2 and SMA 8 Regency Rejang Lebong. This research was done by filling the poll and interview respondents. The result of this research showed that the teacher's barriers to applying the 2013 curriculum at the planning stage of $48 \%$, of the implementation stage of $51,49 \%$, and the evaluation stage of 55,79\%. The difficulties were faced by teachers in implementing the 2013 curriculum at the planning stage of $75.56 \%$, the implementation stage of $92.93 \%$ and evaluation stage of $94.14 \%$. Based on the results the study can be concluded that teachers have difficulties and obstacles in implementing the 2013 curriculum.

Keyword: Curriculum 2013, Teacher difficulties, teacher barriers, planning stage, implementation stage, and stage evaluation

\section{PENDAHULUAN}

Perubahan dan penyempurnan kurikulum sangat dipengaruhi oleh perkembangan zaman, oleh karena itu pada saat ini kurikulum yang berlaku di Indonesia adalah kurikulum 2013 menggantikan kurikulum sebelumnya yaitu kurikulum KTSP 2006 (1). Pada kurikulum KTSP tahun 2006 masih terdapat masalah antara lain : konten kurikulum yang masih terlalu banyak, belum menggambarkan domain sikap,keterampilan dan pengetahuan, serta standar penilaian yang belum mengarah pada penilaian berbasis kompetensi (proses dan hasil). Oleh karena itu, kurikulum 2013 memberi jawaban atas permasalahan yang melekat pada kurikulum KTSP 2006. Kurikulum 2013 bertujuan untuk mendorong peserta didik atau siswa mampu lebih baik dalam melakukan observasi, bertanya, bernalar, dan mengomunikasikan (mempresentasikan) yang diperoleh atau diketahui setelah siswa menerima materi pembelajaran 
Pendekatan Scientific disebut juga pendekatan ilmiah. Proses pembelajaran dapat disatukan dalam suatu proses ilmiah. Karena itu, kurikulum 2013 mengamanatkan esensi pendekatan Scientific dalam pembelajaran. Pendekatan ilmiah inilah yang diyakini dapat mengembangkan sikap, keterampilan, dan pengetahuan peserta didik (2). Untuk memperkuat pendekatan ilmiah (Scientific) perlu diterapkannya pembelajaran berbasis penyikapan/penelitian (Discovery/ Inquiry Learning). Untuk mendorong kemampuan peserta didik untuk menghasilkan karya kontekstual menggunakan pendekatan pembelajaran yang menghasilkan karya berbasis pemecahan masalah (Project Based Learning) (3). Kurikulum 2013 menerapkan pendekatan Scientific menggunakan model pembelajaran Discovery Learning, Inquiry Learning dan Project Based Learning.

Model pembelajaran mengacu pada pendekatan pembelajaran yang akan digunakan, termasuk di dalamnya tujuan-tujuan pengajaran, tahap-tahap dalam kegiatan pembelajaran, lingkungan pembelajaran, dan pengelolaan kelas (4). Model Pembelajaran adalah bentuk pembelajaran yang tergambar dari awal sampai akhir yang disajikan secara khas oleh guru. Dengan kata lain, model pembelajaran merupakan bungkus atau bingkai dari penerapan suatu pendekatan, metode, strategi, dan teknik pembelajaran (5).

Metode pembelajaran merupakan cara atau teknik yang digunakan oleh pendidik untuk menangani suatu kegiatan pembelajaran yang mencakup antara lain ceramah, tanya-jawab, dan diskusi (6). Pada kurikulum 2013, metode yang digunakan adalah metode ceramah, metode tanyajawab dan metode diskusi, dimana metode ini digunakan guru sesuai dengan acuan yang terdapat pada kurikulum 2013 sesuai dengan pendekatan Scientific demi terwujudnya aspek afektif, aspek kognitif dan aspek psikomotorik.

Menurut kurikulum 2013, untuk mengevaluasi/penilaian terhadap hasil metode yang telah diterapkan menggunakan sistem penilaian kegiatan pembelajaran yaitu penilaian autentik. Penilaian autentik (Authentic Assessment) adalah pengukuran yang bermakna secara signifikan atas hasil belajar peserta didik untuk ranah sikap, keterampilan, dan pengetahuan. Penilaian ini berdasarkan acuan yang terdapat pada yaitu penilaian hasil belajar peserta didik pada pendidikan dasar dan pendidikan menengah yaitu meliputi aspek sikap, pengetahuan, dan keterampilan (3).

Kesulitan guru dalam pelaksanaan kurikulum 2013 adalah guru belum sepenuhnya memahami perbedaan antara pendekatan kontekstual dan pendekatan Scientific dalam kegiatan pembelajaran, guru belum sepenuhnya memahami prinsip penilaian di antaranya : cara penilaian kompetensi sikap, cara menilai keterampilan, dan cara menyusun instrumen penilaian sesuai dengan kaidah. Guru masih belum dapat melaksanakan kegiatan pembelajaran yang sesuai dengan standar proses meliputi: belum terbiasa menyampaikan kompetensi yang akan dicapai kepada peserta didik, belum melaksanakan pembelajaran kontekstual dan saintifik, belum memfasilitasi peserta didik mengolah/menganalisis informasi untuk membuat kesimpulan, belum menggunakan media pembelajaran yang bervariasi, dan media yang digunakan belum menghasilkan pembelajaran yang yang menarik (7).

Hambatan yang dialami guru yaitu pada tahap penyusunan perangkat pengajaran yaitu keharusan menyesuaikan RPP berdasarkan Kurikulum 2013. Guru kesulitan dalam mengalokasikan waktu, guru sulit menentukan metode pembelajaran yang sesuai dengan materi, guru masih kesulitan dalam menggunakan berbagai sumber belajar. Guru hanya menggunakan satu jenis buku paket, dan Guru sulit untuk membuat pedoman penskoran (8).

Guru kesulitan dalam menerangkan materi pembelajaran yang bersifat kontekstual. Selain itu, saat pelaksanaan pembelajaran berlangsung, guru tidak menggunakan RPP sebagai acuan, karena guru tidak membuat RPP sendiri, melainkan hanya men-download dari internet. Jadi, antara RPP dengan pelaksanaan pembelajaran banyak ketidaksesuaian, padahal mampu dan tidaknya guru dalam merancang RPP sangat menentukan keberhasilan dalam proses pembelajaran (9).

Kendala-kendala yang menjadi hambatan bagi guru Fisika SMA dalam menerapkan modelmodel pembelajaran yang ditentukan pada Kurikulum 2013 yaitu perubahan format RPP, alokasi waktu dan tahapan dalam mengorganisasi dalam melaksanakan model pembelajaran Kurikulum 2013, dan melaksanakan penilai kompetensi sikap (10). 
Kesulitan guru dalam melakukan tahapan pelaksanaan pembelajaran dengan pendekatan saintifik yaitu seperti memotivasi siswa untuk belajar, menyampaikan tujuan pembelajaran, melaksanakan kegiatan 5M (mengamati, menanya, mengumpulkan data/informasi, menalar dan mengomunikasikan) dan merefleksikan rangkaian aktivitas pembelajaran, guru sedikit terkandala dengan kesiapan dan keaadaan peserta didik, dimana peserta didik sulit untuk diberi motivasi belajar (11).

Format penilaian yang harus dibuat oleh guru dengan ketersediaan waktu yang guru miliki terbatas dan jumlah peserta didik yang banyak membuat guru kesulitan dalam melaksanakan penilaian autentik sesuai dengan tuntutan yang ada pada kurikulum 2013 (12). Guru masih nyaman menggunakan media yang bersifat konvensional dan media cetak seperti LKS dan Modul dalam menyampaikan pembelajaran. Faktor yang menyebabkan adalah karena guru-guru tersebut memiliki penguasaan teknologi yang kurang (13).

Berdasarkan hasil observasi di SMA N 8 Rejang Lebong, Magang 2 di SMA N 6 Kota Bengkulu dan study literature diketahui bahwa komponen kurikulum terdiri atas 4 yaitu tujuan, materi/isi, metode/strategi pembelajaran, dan evaluasi. Komponen tersebut tersebut saling berhubungan antara satu dengan yang lainnya. Dari hasil pengamatan pada saat observasi di sekolah pada saat magang 2 di SMA 8 Rejang Lebong, keempat komponen itu sangat berpengaruh terhadap suatu kegiatan pembelajaran di dalam kelas, karena untuk mencapai tujuan dari pembelajaran terdapat komponen lainnya yang harus diterapkan seperti isi/materi, strategi/metode serta evaluasi.

Ketika guru mengajar di kelas menerapkan komponen-komponen yang ada pada kurikulum dalam kegiatan pembelajaran seperti silabus, RPP, strategi, matode pembelajaran, serta evaluasi yang di lakukan setelah kegiatan pembelajaran. Pada tahap perencanaan pembelajaran, komponenkomponen tersebut sudah banyak sesuai dengan kurikulum 2013, seperti guru sudah membuat silabus, RPP, strategi dan metode yang akan digunakan. Pada tahap pelaksaan masih banyak tidak sesuai dengan apa yang telah direncanakan, seperti masih banyaknya guru yang menggunakan model dan metode yang tidak sesuai dengan rencana yang disusun sesuai dengan kurikulum 2013. Kemudian masih banyaknya yang tidak sesuai antara tujuan dengan materi yang akan di sampaikan pada tahap pelaksaan pembelajaran.

Selanjutnya pada tahap evaluasi guru merasa kesulitan dalam melakukan evaluasi atau penilaian terhadap hasil belajar siswa yang sesuai dengan kurikulum 2013. Dari uraian tersebut, guru merasa kesulitan dalam menerapkan kurikulum 2013, karena adanya hambatan yang menyebabkan guru merasa kesulitan dalam menerapkan kurikulum 2013.

Oleh karena itu perlu di lakukannya penelitian yang berjudul "Deskripsi Hambatan Dan Kesulitan Guru Fisika SMA Se-Kabupaten Rejang Lebong Dalam Menerapkan Kurikulum 2013 ”. Untuk mengetahui hambatan yang menyebabkan guru merasa kesulitan dalam menerapkan kurikulum 2013. Adapun rumusan masalah dalam penelitian ini adalah (1) Apakah kesulitankesulitan yang dialami guru fisika SMA se-kabupaten Rejang lebong dalam menerapkan kurikulum 2013, (2) Apakah hambatan-hambatan yang dialami guru fisika SMA se-kabupaten Rejang lebong dalam menerapkan kurikulum 2013.

\section{METODELOGI PENELITIAN}

Penelitian ini merupakan penelitian deskriptif kualitatif metode survey yang mendeskripsikan masalah-masalah yang dialami guru fisika se-kabupaten rejang lebong dalam menerapkan kurikulum 2013. Subjek penelitian ini adalah 9 guru fisika sma yang terdiri dari 3 orang masingmasing sekolah yaitu SMA 1, SMA 2 dan SMA 8 Kabupaten Rejang Lebong.

Teknik pegumpulan data yang digunakan adalah menggunakan angket dan wawancara. Data yang didapat dari angket yaitu deskripsi kesulitan guru fisika SMA dalam menerapkan kurikulum 2013. Data dari wawancara yaitu deskripsi hambatan kesulitan guru fisika SMA dalam menerapkan kurikulum 2013.

Instrumen pada penilitian ini berupa pertanyaan angket dan wawancara. Sebelum digunakan instrumen terlebih dahulu di uji validitas dan realibilitas oleh ahli. Uji validitas digunakan untuk 
mengetahui kevalidan instrumen yang akan di lakukan. Uji yang digunakan yaitu uji validitas butir angket dan uji realibilitas angket.

Sebelum di gunakan instrumen di uji validitas terlebih dahulu, rumus untuk mencari validitas instrumen adalah sebagai berikut:

$$
r_{x y}=\frac{N \sum X Y-\left(\sum X\right)\left(\sum Y\right)}{\sqrt{N \sum X^{2}-\left(\sum X\right)^{2}\left(N \sum Y^{2}-\left(\sum Y\right)^{2}\right.}}
$$

dengan $r_{x y}$ adalah angka indeks validitas angket, $\sum X$ adalah jumlah skor terendah, $\sum Y$ adalah jumlah skor tertinggi dan $N$ adalah jumlah responden (14).

Kemudian setelah di dapat hasil validitas mencari realibilitas instrumen, untuk mencari realibilitas menggunakan rumus yaitu:

$$
r_{11}=\frac{2 r_{1 / 21 / 2}}{1+r_{1 / 21 / 2}}
$$

dengan $r_{11}$ adalah reliabilitas instrumen, dan $r_{1 / 21 / 2}$ adalah indeks korelasi antara dua belahan instrumen (14).

Teknik analisis data yang digunkan yaitu denga menggunkan teknik deskriptif kualitati yang menghasilkan data dalam bentuk presentase. Hasil perhitungan dalam bentuk presentasedi masukkan dalam tabel kategori presentase. Untuk mencari presentase kesulitan dan hambatan menggunakan rumus yaitu:

$$
P=\frac{F}{N} \times 100 \%
$$

dengan $\mathrm{P}$ adalah persentase kesulitan dan hambatan, $\mathrm{F}$ adalah nilai yang diperoleh responden dan $\mathrm{N}$ adalah jumlah responden (15). Interpretasi presentase skor yang diperoleh di hitung dengan berdasarkan skor perolehan tiap butir, untuk skla linkert dengan presentase pencapaian skor interpretasi skala likert bisa di lihat pada tabel 1 di bawah ini:

Tabel 1. Kategori Presentase Kesulitan

\begin{tabular}{cc}
\hline Interval Persentase & Kategori \\
\hline $81 \%-100 \%$ & Sangat Sulit \\
$61 \%-80 \%$ & Sulit \\
$41 \%-60 \%$ & Cukup Sulit \\
$21 \%-40 \%$ & Tidak Sulit \\
$0 \%-20 \%$ & Sangat Tidak Sulit \\
\hline
\end{tabular}

Tabel 2. Kategori Presentase Hambatan

\begin{tabular}{cc}
\hline Interval Persentase & Kategori \\
\hline $81 \%-100 \%$ & Sangat Terhambat \\
$61 \%-80 \%$ & Terhambat \\
$41 \%-60 \%$ & Cukup Terhambat \\
$21 \%-40 \%$ & Tidak Terhambat \\
$0 \%-20 \%$ & Sangat Tidak Terhambat \\
\hline
\end{tabular}

dengan adanya tabel di atas tersebut, peneliti dapat melihat presentase hasil kesulitan dan hambatan yang di peroleh.

\section{Hasil dan Pembahasan}

3.1.1 Identifikasi Kesulitan yang dialami guru fisika dalam menerapkan kurikulum 2013

Analisis kesulitan pada tahap perencanaan, tahap pelaksanaan dan tahap evaluasi yang dialami guru fisika dalam menerapkan kurikulum 2013. Dari tabel 1 menunjukkan bahwa guru cukup mengalmi kesulitan dalam menerapkan kurikulum 2013 sebesar 52\%. Pada tahap perencaannan sebesar 48\%, Tahap pelaksanaan sebesar 51,49\%, dan tahap evaluasi sebesar 59,79\%. Untuk data hasil yang kesulitan yang di peroleh dapat di lihat pada tabel 3 di bawah ini : 
Tabel 3. Kesulitan Guru dalam Menerapkan Kurikulum 2013

\begin{tabular}{llcccc}
\hline \multicolumn{1}{c}{ Tahap } & \multicolumn{1}{c}{ Indikator } & $\begin{array}{c}\text { Kesulitan } \\
\text { Presentase }\end{array}$ & $\begin{array}{c}\text { Rata-rata } \\
\text { per tahap }\end{array}$ & Keseluruhan & Keterangan \\
\hline Tahap & Silabus & $49,63 \%$ & & & \\
Perencanaan & RPP & $49,52 \%$ & $48 \%$ & & \\
& Media & $44.07 \%$ & & & \\
Tahap & Materi Ajar & $46,67 \%$ & & & \\
Pelaksanaan & Pendekatan Scientific & $56,85 \%$ & & & \\
& Model Pembelajaran & $57,26 \%$ & & & \\
Tahap & Metode Pembelajaran & $45,19 \%$ & $51,49 \%$ & & Cukup \\
Evaluasi & Penilaian Autentik & $62,22 \%$ & & & \\
& Penilaian Sikap & $53,33 \%$ & & & \\
& Penilaian Psikomotorik & $52,22 \%$ & & & \\
& Penilaian Kognitif & $55,28 \%$ & $55,79 \%$ & & \\
\hline
\end{tabular}

Berdasarkan tabel 3 di atas di ketahui bahwa pada tahap perencaannan sebesar 48\%, tahap pelaksanaan sebesar 51,49\%, dan tahap evaluasi sebesar 59,79\%. Pada tahap evaluasi guru mengalami kesulitan dalam penilaian autentik sebesar 62,22\%. Pada indikator penililaian sikap, psikomotorik, dan kognitif guru cukup mengalami kesulitan sebesar 53,33\%;52,22\%;55,28\%. Tahap Pelaksanaan guru cukup mengalami kesulitan dalam indikator materi ajar sebesar 46,67\%, pendekatan scientific $56,85 \%$, model pembelajaran $57,26 \%$, metode pembelajaran $45,19 \%$. Tahap perencanaan guru cukup mengalmi kesulitan dalam indikator silabus sebesar 49,63\%, RPP 49,52\%, dan media $44,07 \%$.

3.1.2 Identifikasi Hambatan yang dialami guru fisika dalam menerapkan kurikulum 2013

Analisis hambatan pada tahap perencanaan, tahap pelaksanaan dan tahap evaluasi yang dialami guru fisika dalam menerapkan kurikulum 2013. Dari tabel 4 menunjukkan bahwa guru sangat mengalami hambatan dalam menerapkan kurikulum 2013 sebesar 87,47\%. Pada tahap perencanaan hambatan sebesar 75,56\%, tahap pelaksanaan sebesar $92,93 \%$ dan tahap evaluasi sebesar 94,14\%. Pada tahap evaluasi pembelajaran hambatan yang di alami guru rata-rata sebesar 94,14\%. Hambatan yang dialami indikator pada indikator penilaian autentik sebesar $100 \%$, penilaian sikap sebesar $100 \%$, penilaian psikomotorik sebesar $100 \%$ dan penilaian kognitif sebesar $87,50 \%$ dengan kategori sangat terhambat. Pada tahap pelaksanaan pembelajaran hambatan yang dialami guru rata-rata sebesar $92,93 \%$. Untuk data hasil yang hambatan yang diperoleh dapat di lihat pada tabel 4 di bawah ini :

Tabel 4. Hambatan Guru dalam Menerapkan Kurikulum 2013

\begin{tabular}{clcccc}
\hline Tahap & \multicolumn{1}{c}{ Indikator } & $\begin{array}{c}\text { Kesulitan } \\
\text { Presentase }\end{array}$ & $\begin{array}{c}\text { Rata-rata } \\
\text { per tahap }\end{array}$ & Keseluruhan & Keterangan \\
\hline Tahap Perencanaan & Silabus & $44,44 \%$ & & & \\
& RPP & $71,43 \%$ & $75,56 \%$ & & \\
Tahap Pelaksanaan & Media & $100 \%$ & & & \\
& Materi Ajar & $66,67 \%$ & & & \\
& Pendekatan Scientific & $100 \%$ & & & Sangat \\
& Model Pembelajaran & $100 \%$ & & & \\
Tahap Evaluasi & Metode Pembelajaran & $72,22 \%$ & $92,93 \%$ & \multirow{2}{*}{ Terhat } \\
& Penilaian Autentik & $100 \%$ & & & \\
& Penilaian Sikap & $100 \%$ & & & \\
& Penilaian & $100 \%$ & & & \\
& Psikomotorik & & $94,14 \%$ & & \\
& Penilaian Kognitif & $87,50 \%$ & & & \\
\hline
\end{tabular}

Berdasarkan tabel 4 di atas di ketahui bahwa pada tahap perencanaan pembelajaran hambatan yang dialami rata-rata guru seesar 75,56\% Hambatan yang di alami guru pada indikator silabus sebesar $44,44 \%$ dengan kategori cukup terhambat, penyusunan RPP sebesar $71,43 \%$ dengan kategori terhambat, peyusunan media sebesar $100 \%$ dengan kategori sangat terhambat. 
Pada tahap pelaksanaan pembelajaran hambatan yang dialami guru rata-rata sebesar $92,93 \%$. Hambatan yang dialami guru pada indikator materi ajar sebesar 66,67\% dengan kategori terhambat, pendekatan scientific sevesar $100 \%$ dengan kategori sangat terhambat, model pembelajaran sebesar $100 \%$ dengn kategori sangat terhambat, dan metode pembelajaran sebesar 72,22\% dengan kategori terhambat. Tahap perencanaan pembelajaran hambatan yang dialami rata-rata guru seesar $75,56 \%$. Hambatan yang di alami guru pada indikator silabus sebesar 44,44\% dengan kategori cukup terhambat, penyusunan RPP sebesar 71,43\% dengan kategori terhambat, peyusunan media sebesar $100 \%$ dengan kategori sangat terhambat.

\subsection{Pembahasan}

Penelitian ini mendeskripsikan kesulitan dan hambatan guru fisika SMA dalam menerapkan kurikulum 2013. Kesulitan yang dimaksud adalah kesulitan yang dirasa guru yang berasal dari dirinya sendiri. Sedangkan hambatan adalah hal diluar diri pribadi guru yang menyebabkan guru merasa kesulitan.

A. Kesulitan guru fisika SMA dalam menerapkan kurikulum 2013

Pada tahap perencanaan guru cukup mengalami kesulitan dalam indikator silabus sebesar $49,63 \%$, penyusunan RPP sebesar 49,52\%, penentuan media sebesar 44,07\%. Kesulitan yang guru alami dalam tahap perencanaan ini yaitu kesulitan guru dalam menentukan model pembelajaran yang akan digunakan seperti yang telah di anjurkan oleh silabus. Kesulitan yang dialami guru dalam penyusunan RPP antara lain dalam memahami model pembelajaran yang akan digunakan seperti guru kurang memahami bagaimana langkah-langkah model pembelajaran yang akan di terapkan dalam penyusunan RPP. Kesulitan guru dalam menentukan media pembelajaran yang akan digunakan seperti memahami penggunaan KIT, penyusunan LKPD dan e-modul dalam kegiatan perencanaan pembelajaran.

Pada tahap pelaksanaan guru cukup mengalami kesulitan sebesar 51,49\% antara lain pada aspek materi ajar sebesar 46,67\%, Pendekatan Scientific sebesar 56,85\%, Model pembelajaran sebesar 57,26\%, dan metode pembelajaran sebesar 45,19\%. Kesulitan yang dialami guru pada tahap pelaksanaan antara lain kesulitan guru dalam menggunakan pendekatan scientific seperti kesulitan dalam membangkitkan rasa ingin tahu siswa, mendorong siswa untuk aktif bertanya, dan membiasakan siswa untuk berfikir spontan dalam kegiatan pembelajaran. Kesulitan guru dalam penerapan model-model pembelajaran seperti kesulitan guru pada tahap stimulation, problem statment, dan data collection dalam model discovery learning. Kesulitan guru pada tahap orientasi, tahap organisasi siswa dalam belajar, dan penyelidikan mandiri siswa dalam menerapkan model pembelajaran Problem based learning. Dalam menerapakan model Project Based Learning kesulitan yang dialami guru pada tahap penyajian masalah, tahap pembuatan rencana dan tahap penyusunan jadwal.

Kesulitan guru dalam menerapkan metode pembelajaran yaitu kesulitan guru dalam mengontrol kelas, menyajiakan materi yang luas dalam menggunakan metode pembelajaran pada kegiatan pembelajaran di kelas. Kesulitan guru dalam menggunakan alat demonstrasi dan alat bantu yang digunakan untuk mendukung metode pembelajaran yang digunakan. Pada tahap evaluasi kesulitan yang alami guru sebesar 55,79\%, antara lain pada indikator penilaian Autentik 62,22\%, penilaian sikap sebesar 53,33\%, penilaian psikomtorik sebesar $52,22 \%$ dan penilaian kognitif sebesar $55,28 \%$. Dalam penilaian sikap kesulitan guru pada aspek konsep diri,nilai dan minat siswa dalam kegiatan pembelajaran

Pada penilaian psikomotorik kesulitan yang dialami guru yaitu dalam penilaian proyek, portofolio, dan penilaian produk dalam kegiatan evaluasi pembelajaran. Dalam penilaian kognitif kesulitan yang dialami guru yaitu kesulitan guru dalam membuat soal pada tingkat aplikasi (C3), tingkat analisis (C4), tingkat evaluasi (C5) dan tingkat kreasi (C6) dalam kegiatan evaluasi pembelajaran.

B. Hambatan guru fisika SMA dalam menerapkan kurikulum 2013

Pada tahap perencanaan guru mengalami hambatan dalam aspek silabus sebesar 44,44\%, penyusunan RPP sebesar 71,43\%, dan media sebesar $100 \%$. Tahap perencanaan pembelajaran hambatan yang dialami guru yaitu pada aspek silabus, hambatan yang dialami guru lebih ke 
penerapan silabus yang telah dibuat seperti alokasi waktu yang yang tidak seimbang antara materi dengan waktu yang di sediakan oleh kurikulum 2013.

Aspek penyusunan RPP hambatan yang guru alami yaitu kesulitan guru pada penyusunan sintaks model, alat penunjang model yang terbatas dan manjemen waktu yang masih kurang. Oleh karena itu guru pada saat penyusunan RPP guru banyak berdiskusi antar guru untuk mencari solusi dari kesulitan yang dialami setiap guru sesuai dengan kaidah penyusunan RPP yang kurikulum 2013. Pada tahap pelaksanaan guru mengalami hambatan pada aspek materi ajar sebesar 66,67\%, pendekatan scientific sebesar $100 \%$ dan metode pembelajaran sebesar $72,22 \%$. Hambatan yang dialami guru pada aspek materi ajar yaitu guru mengalami kesulitan menyesuaikan indikator yang telah di buat di RPP dengan materi yang akan di ajarkan, sehingga tujuan yang hendak di capai pada pelaksanaan masih belum sepenuhnya terpenuhi.

Tahap evaluasi guru mengalami hambatan pada aspek penilaian Autentik sebesar 100\%, penilaian sikap sebesar $100 \%$, penilaian psikomotorik sebesar $100 \%$ dan penilaian kognitif sebesar $87,50 \%$. Pada aspek penilaian sikap hambatan yang dialami guru yaitu kesulitan dalam menilai sikap per indvidu, guru mengalami kesulitan dalam cara mengamit penilaian sikap siswa yang berbeda dalam kegiatan evaluasi dan guru kesulitan dengan format penilaian pada penilaian sikap. Aspek penilaian psikomotorik hambatan yang dialami guru yaitu mengalami kesulitan dalam penilaian portofolio. Hambatan yang di alami oleh guru yaitu guru kesulitan dalam penilaian portofolio kepada siswa yang memunyai kemampuan yang kurang dan guru mengalami kesulitan menilai siswa dengan kemampuan yang berbeda-beda

Aspek penilaian kognitif hambatan yang dialami guru yaitu guru mengalami kesulitan dalam penialain tes lisan dan pembuatan soal dalam kegiatan evaluasi. Kesulitan yang dialami guru saat penilaian lisan adalah pada format penilaian, tes lisan membutuhkan waktu yang panjang untuk melaksanakan, dan terbatas materi yang bisa di nilai pada tes lisan. Kemudian kesulitan guru dalam pembuatan soal, hambatan yang dialami guru yaitu pemahaman tentang kata kerja operasioanal pada setiap tingkatan level kognitif yang di mulai dari $\mathrm{C} 1, \mathrm{C} 2, \mathrm{C} 3, \mathrm{C} 4, \mathrm{C} 5$, dan C6. kesulitan guru terletak pada saat pembuatan soal hots yang mengacu pada level C3-C6 dengan menggunakan KKO taksonomi Bloom atau Anderson yang akan digunakan. Karena pada level C3-C6 ini kebanyakan siswa tidak bisa menjawab soal pada saat penilaian sehingga guru lebih sering menggunakan level C1-C2 dalam kegiatan evaluasi.

\section{Kesimpulan dan Saran}

\subsection{Kesimpulan}

Berdasarkan hasil analisa data dan pembahasan tentang deskripsi hambatan dan kesulitan guru fisika SMA se-Kabupaten Rejang Lebong dalam menerapkan kurikulum 2013 maka dapat disimpulkan bahwa kesulitan dan hambatan yang dihadapi guru dalam menerapkan kurikulum 2013 yaitu pada tahap perencanaan kesulitan dalam menentukan model dan media pembelajaran, Tahap pelaksanaan kesulitan dalam membangkitkan rasa ingin tahu siswa, mendorong siswa untuk aktif bertanya, dan membiasakan siswa berfikir spontan dalam menerapkan pendekatan Scientific. Tahap kesulitan dan hambatan dalam penilaian sikap siswa, penilaian psikomotorik pada aspek penilaian proyek, portofolio serta penilaian produk. Kesulitan dalam penilaian kognitif yaitu pada pembuatan soal tingkat aplikasi (C3), tingkat analisis (C4), tingkat evaluasi (C5), dan tingkat kreasi (C6).

\subsection{Saran}

Saran-saran yang perlu dikemukakan berdasarkan hasil penelitian diatas yaitu: Perlu adanya upaya peningkatan pelatihan guru mengenai persiapan, penerapan dan penilaian dalam mengganakan model-model yang di njurkan dalam kurikulum 2013. serta perlu adanya upaya peningkatan penyediaan sarana dan prasarana terutama alat-alat praktikum sehingga guru tidak mengalami kesulitan dalam kegiatan pembelajaran.

\section{UCAPAN TERIMAKASIH}

Penulis mengucapkan terimakasih kepada validator ahli yaitu Dr Nirwana, M.Pd dan Dr Connie, M.Pd serta Responden guru-guru SMA N 1, 2 dan 8 Kabupaten Rejang Lebong yang sudah 
bersedia untuk membantu pengisian angket dan wawancara studi deskripsi tentang hambatan dan kesulitan yang dialami guru fisika SMA Negeri se-Kabupaten Rejang Lebong dalam menerapkan kurikulum 2013.

\section{DAFTAR PUSTAKA}

1. Anwar R. Hal-Hal Yang Mendasari Penerapan Kurikulum 2013. J Pendidik. 2013;1:97-106.

2. Musfiqon N. Pendekatan Saintifik. 1st ed. Nurdyansyah, editor. Sidoarjo: Nizamia Learning Center; 2015. 18-27 p.

3. Kemendikbud. Permendikbud. Kemendikbud [Internet]. 2013;10-5. Available from: https://www.kemdikbud.go.id/main/blog/2020/06/kemendikbud

4. Lamote H. Kesulitan-Kesulitan GuruMatematika dalam melaksanakan kurikulum 2013 di Madrasah. J Pendidik [Internet]. 2017;10(1):55-72. Available from: http://journal.unj.ac.id/index.php/jipi

5. Kustijono R, Kustijono R. Pandangan guru terhadap pelaksanaan kurikulum 2013 dalam pembelajaran fisika smk di kota surabaya. 2014;4(1):1-14.

6. Mayang, Puspita AD dan H. Identifikasi Kesulitan Guru Ipa dalam Melaksanakan kurikulum 2013 Di SMP Negeri Wonogiri. J Pendidik [Internet]. 2015;11(2033-166):1-4. Available from: http://journal.uny.ac.id/index.php/jipi Jurnal

7. Agus M, Budiyanto K, Waluyo L, Mokhtar A. Implementasi Pendekatan Saintifik dalam Pembelajaran di Pendidikan Dasar di Malang Implementation of Scientific Approach in Education in Primary Education in Malang. J Pendidik [Internet]. 2016;13(1):46-51. Available from: https://jurnal.uns.ac.id/prosbi/article/view/5648

8. Shofiyah N, Sidoarjo UM, Reasoning S. Model Problem Based Learning ( Pbl ) Dalam Melatih Scientific Reasoning Siswa. J Pendidik [Internet]. 2018;3(1):33-8. Available from: https://www.researchgate.net/publication/329015360

9. Setiadi H. Pelaksanaan Penilaian Pada Kurikulum 2013 The Implementation Of Assessment In The Curriculum 2013. J Penelit dan Eval Pendidik [Internet]. 2016;20(2):12. Available from: http://journal.uny.ac.id/index.php/jpep\%0A

10. Bengkayang N. Penyebabnya Dalam Memahami Materi Listrik Dinamis Kelas X Sma Description Of Students ' Learning Difficulties And The Causes On I . Junal Pendidik Fis. 2017;07(01):44-53.

11. Kusnadi,Dedi, Suradi Tahmir DIlM. Implementasi kurikulum 2013 dalam pembelajaran matematika di sma negeri 1 makassar. J Mat dan Pembelajaran. 2014;2:123-35.

12. Yuliana N. Penggunaan Model Pembelajaran Discovery Learning Dalam Peningkatan Hasil Belajar Siswa. 2018;2(April):21-8.

13. Putri RF, Jumadi J. Kemampuan Guru Fisika dalam Menerapkan Model-Model Pembelajaran pada Kurikulum 2013 serta Kendala-Kendala yang Dihadapi Senior High School Physics Teacher' s Ability to Apply The Learning Models of 2013 Curriculum and the Obstacles Faced. J Inov Pendidik IPA [Internet]. 2017;3(2):201-11. Available from: http://journal.uny.ac.id/index.php/jipi Jurnal

14. Arikunto S. Prosedur Penelitian Pendektan Praktik. 15th ed. Jakarta: PT. Rineka Cipta; 2013. $173 \mathrm{p}$.

15. Riduwan. Dasar-Dasar Statistika. 1st ed. Iswarta P wija, editor. Bandung; 2013. 38 p. 